\title{
Underachievement in English Speaking Skills among Kuwaiti EFL Students at the College of Basic Education: Possible Causes and Possible Solutions
}

\author{
Mohammad A. Almutairi \\ Language Center, College of Basic Education, the Public Authority for Applied Education and Training, Kuwait
}

\begin{abstract}
The purpose of this study is to investigate the possible causes and possible solutions of the massive underachievement in speaking skills among Kuwaiti EFL (English as a foreign language) students at the College of Basic Education (CBE). This study involved 331 male and female EFL students who are currently studying different bachelor degree programs at CBE. A questionnaire of 12 statements was used to collect their responses, and then the data was analyzed. After the analysis of the data, the findings indicated that the vast majority of students identified their speaking skills as weak or fair. Their answers revealed there are various factors that hinder in developing their weakness in speaking skills. The most obvious ones were lack of motivation, the lack of speaking skills emphasis in EFL syllabus design, and the absence of technology in ELT (English language teaching), including language laboratories and auditory aids. According to the recommendations of this study, this great challenge could be overcome by four central solutions. First, placing spoken English in the EFL syllabus. Second, including spoken English assessment in the coursework and providing a comfortable environment in class to motivate EFL students to use their target language and encourage them to improve it. Third, the study recommends that EFL teachers join special training courses in the Professional Development Center to learn the basic knowledge of how to use technology in ELT, including language labs. Finally, the researcher ends his recommendations by endorsing the administration of the College of Basic Education to provide modern language labs for the Language Center.
\end{abstract}

Index Terms—EFL speaking skills, English language teaching, TESOL, students' perceptions

\section{INTRODUCTION}

Speaking is considered the most difficult and the most complex of all the four skills, as it needs experience and exposure to the target language. In English language teaching, it is a very crucial part of the learning process and a necessary component of any language education classroom. In this regard, and as an English language practitioner for many years, I have noticed that most of my EFL students suffer from a great weakness in expressing themselves effectively in English. In most cases, they turn to the Arabic language to participate in in-class activities. Almost all the researchers' colleagues have observed this phenomenon in their classrooms. Notably, despite the importance of speaking skills as a fundamental element of the language in the current era of globalization, the emphasis on this significant issue is very rare in the curriculum of the Language Center at the College of Basic Education. For this reason, this study aims to investigate and explore the possible causes and solutions for the underachievement of CBE EFL students from Kuwait in speaking skills in CBE. A questionnaire of 12 statements was distributed to 350 male and female students studying English as a foreign language at CBE. Three hundred and thirty-one students responded to the questionnaire, and their answers showed a real educational problem that needs to be addressed and discussed.

\section{LITERATURE REVIEW}

For any learner of English as a foreign language, it is essential to be efficient in speaking and conversation. Since it is often thought to be the most important skill of language learning, speaking and conversation occupy a central part in most ELT programs (Bygate, 1987; Byrne, 1988; Nolasco \& Lois, 1987). It is the duty of the language teacher to provide necessary help to the learners so that they acquire the desired level of speaking and conversation skills to be competent members of the speech or discourse community concerned (Lave, 1998; Swales, 1990). Conversation skill, a part of speaking ability and communication, requires guided practice for its development (Barker, 2007; Dugas \& DesRosiers, 2010; Garner, 2017; Green \& Burleson, 2003; Worth, 2004). In many cases, learners are found to attain a certain degree of writing skill easily, whereas they often struggle to attain speaking skills to that extent. In speaking, unlike its counterpart productive skill, a person has to face the audience in the immediate environment directly and produce utterances spontaneously without a long time to think, which proves to be a difficult task for them. 
In fact, the biggest challenge for the learners of English as a foreign language is to speak the language accurately and fluently when they are engaged in real conversation. Without a certain degree of conversational competence, the learners cannot talk and communicate their ideas to others. Conversational weakness may be caused by various factors, resulting from a lack of required knowledge and skills in the domains of vocabulary, grammar, and pronunciation, as well as sociological and psychological barriers. Added to them are institutional and pedagogical concerns. Hughes (2011) rightly observes that speaking/conversation is not a discrete but multifaceted skill; it is connected to intralinguistic (sound, word, sentence, discourse, etc.) and extra-linguistic (psychology, physiology, environment, etc.) phenomena. If institutions do not provide a good environment for language learning and usage, and if the learning is not assisted by sound pedagogy, students will not achieve a level of understanding anywhere close to fluency.

The basis of all verbal communication is lexical knowledge. In order to communicate successfully, a person must know the basic words necessitated by the topic of conversation. Vocabulary building is thought to be the first and foremost job of the language learner. The more vocabulary they learn, the more likely they are to be able to sustain conversation. Words are the basic building blocks of any language. In the most fundamental sense, words are the total language. That is why, sometimes, a dictionary becomes representative of a particular language. Experts may differ on how vocabulary can be learned/taught, but they can never argue against its necessity. A study at Ajloun National University identified the lack of sufficient vocabulary of English language learners as the number-one difficulty in the performance of speaking/conversation (Al-Eiadeh, Al-Sobh, Al-Zoubi, \& Al-Khasawneh, 2016).

After learning words, the learners must also know how they can be combined into meaningful sentences. That is where grammar comes in. A person must know the rules of sentence formation to speak efficiently. With only singleword utterances, one cannot be a good speaker. Thoughts are meant to be expressed in the form of complete sentences, but even then, the message may not be properly communicated to the listener. Grammatical errors may jeopardize the intended meaning and cause miscommunication. Learning grammar can be explicit and implicit, but it must be learned to become a successful language user.

To make an ELT program successful, teachers need to know the psychological aspects of language learning and use them, which is basically a cognitive process (Molder and Potter, 2005; Turnbull, 2003). When students are engaged in the learning process, they need to be motivated intrinsically or instrumentally. It is the responsibility of teachers to highlight the importance of language learning to strongly motivate students. Teachers should also encourage students with positive feedback and remove any mental setbacks (e.g., fear and anxiety). If learners can overcome their fear of learning and speaking, they often gain confidence and make efforts to become successful language learners and users. As Boonkit (2010) noticed, apart from competence, confidence is crucial for the development of speaking/conversational skills.

An institution has a significant role in producing good language learners. It can provide a congenial teaching/learning atmosphere inside and outside the classroom so learners may practice conversation anywhere. Frequent practice is the gateway to efficient conversation. Bilbrough (2007) recommended both authentic and scripted dialogue practices for rapid improvement. Pair/group practice that manifests collaborative learning is of utmost necessity in and outside the classroom (Sasson, 2013). The practice may also be based on discussion (Henning, 2008). Students may practice listening in the language laboratory or self-access center to boost their skills in speaking and pronunciation. Pronunciation software may be of special help to students (Bailey, 2005, p. 180). Nowadays, YouTube videos are also used to aid learners in enhancing listening and speaking skills. It is even possible for teachers to provide help to learners online. In a study in Russia, Kozar (2018) found that online conversation lessons were highly satisfying for learners. Lin, You, Shen, Qi, and Luo (2017) noticed the positive effect of mobile social networking on English speaking skills in China.

\section{SIGNIFICANCE OF THE STUDY}

Besides the researcher's personal interest in developing and improving the ELT curriculum in Kuwait, the results of this study will provide some insights and information towards redefining the current EFL syllabus at the College of Basic Education. Decision-makers and EFL textbook designers in Kuwait might find the study and its conclusions a useful start towards evaluating the current ELT curriculum and including speaking skills in the syllabus. In fact, due to the shortage of empirical studies that examine the speaking skills of Kuwaiti EFL learners, this study takes on a pioneering role. Therefore, this study could provide the basis for researchers' future studies in the Kuwaiti context.

\section{METHODOLOGY}

This study aimed to find the possible causes of and the possible solutions for underachievement in speaking skills among Kuwaiti EFL students at the CBE. The researcher decided to use the quantitative method since it is the best one for gathering data from a tremendous number of participants.

\section{A. Research Tools}

A questionnaire of 12 statements was used by the researcher to gather his data. A questionnaire of a similar study was borrowed. It was amended by the researcher, and the statements were raised from 10 to 12 so as to cover more aspects 
of the study to suit the sitting in CBE. Then, it was distributed to 200 male and female EFL students. Every statement had these options - I agree, I don't know, or I disagree — except statement 1, which tested their level of speaking skills and had the following options: excellent, very good, fair, and weak.

\section{B. Participants}

The participants of this study were 200 male and female Kuwaiti students pursuing BA degrees in various specialties at the CBE. Their ages range from 18 to 24 years old. During their BA studies, they have to take three English courses: English 099, English 1, and English 2.

\section{RESEARCH QUESTION}

As the main purpose of the study is to learn both the possible reasons behind the weakness of the speaking skills of Kuwaiti EFL students from CBE and the suggested solutions for combating the phenomena, this study addresses the following questions:

1-What are the possible causes for underachievement in speaking skills among Kuwaiti students from CBE?

2-What are the possible solutions for the underachievement in speaking skills among Kuwaiti students at CBE?

\section{RESULTS AND DISCUSSION}

Statement 1 was designed by the researcher to identify the speaking abilities of EFL students at CBE and to verify that the problem exists. An overview of the participants' responses on Statement 1, which examined their level of speaking skills, showed that most of the participants in the college (138: 41.7\%) answered with weak, almost one third (104: 31.4\%) identified their level as fair, a few participants (43: 14.5\%) answered with very good, and a few participants (48: 14.5\%) answered with excellent (Table 1). This shows that this problem is common among EFL students and needs to be addressed and discussed by the principals.

Statement 2 asked the EFL students if the Language Center offers special English courses for enhancing students' speaking skills like conversational English. The majority of them (264:79.8\%) disagreed, a few participants agreed $(63: 19 \%)$ and just a few (4:1.2\%) (Table 1). This result shows that the focus on teaching speaking skills is almost unavailable in the Language Center curriculum.

The participants' replies on Statement 3 showed that the great majority of them (256:77\%) admitted that their classes have huge numbers of students, and these unacceptable numbers in classrooms hinder teachers from employing any speaking skills in their settings. Only $(63: 19 \%)$ disagreed that huge numbers of participants are considered as an obstacle for learning speaking skills and (12:3.6\%) had no idea (Table 1).

Regarding the responses of EFL students on Statement 4, which examined their EFL syllabus, once again, the vast majority of them (244:73.7\%) agreed that their textbooks don't focus on speaking skills. On the contrary, $(77: 23.3 \%)$ of the participants disagreed with the statement, and (10:3\%) had no idea (Table 1).

Because language laboratories play a very important role in enhancing EFL students' speaking skills, Statement 5 was about using language labs by the EFL teachers for training and enhancing their EFL students' speaking skills. Unfortunately, almost all the participants (314:94.9) answered that no language labs were available at the College of Basic Education (Table 1), (13:3.9) disagreed with the statement, and (4:1.2\%) had no idea. Not using the technology for practicing speaking skills could have contributed to the existence of this problem. Actually, their answers to Statement 5 proved once again that speaking skills are being kept out of the EFL syllabus and surely are not being made a priority by the principals.

Statement 6 asked the students about their motivation to learn and use English when speaking inside and outside of the classroom. Regrettably, the vast majority (314:94.9) of EFL students expressed their lack of motivation to speak English inside or outside of class (Table 1). This demotivation could have happened for various reasons, including the absence of a speaking assessment during the course, as will be mentioned in the discussion of Statement 11.

Concerning Statement 7, which asked EFL students about English language usage in EFL classes, most students (287:86.7) agreed with the statement that using the English language as a way of communicating with the teacher in the class was too infrequent; some students (39:11.8\%) disagreed with Statement 7; and other students $(5: 1.5 \%)$ had no idea (Table 1).

Statement 8 is very similar to Statement 7 in that it asks the students about using their native language in their EFL classes with their teachers. The great majority of participants (96.1:93.7\%) answered that they turn to Arabic if they want to ask their EFL teachers about any topic regarding the lessons. Only a few (11:3.3\%) disagreed with Statement 8 , and very few $(2: 0.6 \%)$ had no idea (Table 1$)$.

Statement 9 was an estimation by the EFL students for their speaking skills syllabus in the college. Unfortunately, the vast majority of EFL students (310:93.7\%) replied that speaking skills taught by EFL teachers is very limited and is not a priority. A few of them (18:5.4\%) disagreed with this statement, and very few (3:9\%) had no idea (Table 1).

Statement 10 asked the participants if the time of their classes was enough to learn speaking skills. Again, the great majority (270:81.6\%) replied that time in the class was enough, and there was always room for learning speaking skills. 
Only 43:13\% disagreed and replied that the time was not enough for learning speaking skills, and 18:5.4\% had no idea (Table 1).

As mentioned above in Statement 6, the students lacked motivation for using speaking skills in and out of the class. This state of motivation could be justified in their responses to Statement 11. In Statement 11, the participants were asked whether there was a score for speaking skills in the distribution of marks for the English courses the students were taking. Once more, a massive number of participants (309 or 93.4\%) answered that there was no assessment done by their EFL teachers for speaking skills in the three modules of English language, 12 (or 3.6\%) of the participants disagreed with the statement, and $10(3 \%)$ had no idea (Table 1). This could be the main reason why the EFL students were not motivated to use or develop their speaking skills. In the same regard, as part of the teaching staff of the Language Center, I follow the same distribution of marks issued by the department: 30 marks for the mid-term exam, 10 marks for attendance, 10 marks for quizzes, and 50 marks for the final exam. The assessment of speaking skills is not used. This is more evidence that speaking skills have no priority or focus in the EFL curriculum at CBE.

Statement 12 was designed to explore the students' opinions of whether shyness was an obstacle for practicing their English or if shyness could have hindered them from using their speaking skills. Of the participants, 187 (56.5\%) agreed with this statement, while $126(38 \%)$ disagreed, and only $18(5.4 \%)$ were not sure (see table 1$)$.

TABLE 1

KuWAiti EFL Students’ ResPonses To The STATEMENTS ABOUt IMPROVING THEIR SPEAKING SKILLS

\begin{tabular}{|c|c|c|c|c|c|c|}
\hline & agree & & disagree & & don't know & \\
\hline Statement & frequency & percent & frequency & percent & frequency & percent \\
\hline $\begin{array}{l}\text { 2- The Language Center at the College of } \\
\text { Basic Education doesn't offer } \\
\text { (conversational English courses) to } \\
\text { improve and enhance the speaking and } \\
\text { conversational kills }\end{array}$ & 264 & 79.8 & 63 & 19 & 4 & 1.2 \\
\hline $\begin{array}{l}\text { 3- The large number of students in EFL } \\
\text { classrooms is an obstacle for using } \\
\text { speaking skills in-class. }\end{array}$ & 256 & 77.3 & 63 & 19 & 12 & 3.6 \\
\hline $\begin{array}{l}\text { 4-speaking skills are part of EFL } \\
\text { syllabus. }\end{array}$ & 244 & 73.7 & 10 & 3 & 77 & 2.3 \\
\hline $\begin{array}{l}\text { 5- Language labs are not available in the } \\
\text { college. }\end{array}$ & 314 & 94 & 4 & 1.2 & 13 & 3.9 \\
\hline $\begin{array}{l}\text { 6- There are no motivations like giving } \\
\text { grades or encouragement from EFL } \\
\text { teachers to use and practice our spoken } \\
\text { English. }\end{array}$ & 314 & 94.9 & 17 & 5.1 & 0 & 0 \\
\hline $\begin{array}{l}\text { 7- Speaking and communicating with our } \\
\text { EFL teacher in English language are } \\
\text { little. }\end{array}$ & 287 & 86.7 & 39 & 11.8 & 5 & 1.5 \\
\hline $\begin{array}{l}\text { 8- Most of the time, we use Arabic in } \\
\text { class during English classes. }\end{array}$ & 318 & 96.1 & 11 & 3.3 & 2 & 6 \\
\hline $\begin{array}{l}\text { 9- Teaching us how to practice speaking } \\
\text { skills during our study to English courses } \\
\text { in the college is very limited. }\end{array}$ & 310 & 93.7 & 18 & 5.4 & 3 & .9 \\
\hline $\begin{array}{l}\text { 10- The time of English classes is short } \\
\text { and is not enough to give a chance for } \\
\text { practicing speaking skills. It could be an } \\
\text { obstacle for improving speaking skills. }\end{array}$ & 270 & 81.6 & 43 & 13 & 18 & 5.4 \\
\hline $\begin{array}{l}\text { 11- The assessment of speaking skills is } \\
\text { not part of the coursework. There are no } \\
\text { marks for speaking skills in the } \\
\text { distribution of marks in English courses. }\end{array}$ & 309 & 93.4 & 12 & 3.6 & 10 & 3.7 \\
\hline $\begin{array}{l}\text { 12-Shyness makes it difficult for me to } \\
\text { use my spoken English with my } \\
\text { classmates and outside. }\end{array}$ & 187 & 56.8 & 126 & 38.1 & 18 & 5.4 \\
\hline
\end{tabular}

\section{CONCLUSIONS AND RECOMMENDATIONS}

As previously mentioned, this study aims to investigate and examine the reasons why Kuwaiti EFL students cannot reach a certain degree of fluency in speaking English. It also aims to provide educational suggestions and recommendations to enhance the English-speaking skills. According to the findings of this study and depending on the highest responses of the participants, it is concluded that the weakness of spoken English among Kuwaiti EFL students at $\mathrm{CBE}$ could be a result of three causes. Firstly, ignoring speaking skills from the EFL syllabus caused the deterioration of the problem. Secondly, excluding students' oral assessment from the coursework helped to create a state of demotivation among EFL students. Thirdly, there was an absence of new technology in ELT, including language labs that do not exist in CBE.

Given the above causes, the following solutions (suggestions) can help improve the speaking skills of EFL students: 
- Spoken English should be included in the EFL syllabus. This could include speaking practices, dialogues, and presentations.

- Spoken English should be assessed within the coursework. This will motivate students to use their speaking skills in class.

- EFL teachers should provide a comfortable environment in class for EFL students to use their English. This includes encouraging students to participate in oral activities.

- EFL teachers should join special training courses in using technology in classrooms, including courses on how to operate the language labs.

- The Administration of the College of Basic Education should provide the up-to-date language labs for the Language Center to train students in using their speaking skills, especially if the budget is available.

\section{REFERENCES}

[1] Al-Eiadeh, A. R., Al-Sobh, M. A., Al-Zoubi, S. M., \& Al-Khasawneh, F. (2016). Improving English Language Speaking Skills of Ajloun National University Students. International Journal of English and Education, 5(3), 181-195.

[2] Bailey, K. (2005). Practical English Language Teaching: Speaking. New York: McGraw-Hill.

[3] Barker, A. (2007). Improve Your Communication Skill. $2^{\text {nd }}$ ed. London: Kogan Page.

[4] Bilbrough, N. (2007). Dialogue Activities: Exploring Spoken Interaction in the Language Class. Cambridge: Cambridge University Press.

[5] Boonkit, K. (2010). Enhancing the development of speaking skills for non-native speakers of English. Procedia - Social and Behavioral Sciences. 2(2), 1305-1309.

[6] Bygate, M. (1987). Speaking. Oxford: Oxford University Press.

[7] Byrne, D. (1988). Teaching Oral English. London: Longman.

[8] Dugas, D. W., \& DesRosiers, R. T. (2010). Speaking by Speaking: Skills for Social Competence. St. Petersburg, FL: Compass Publishing.

[9] Garner, A. (2017). Conversationally Speaking: Tested New Ways to Increase Your Personal and Social Effectiveness. Kindle edition. New York: McGraw-Hill Education.

[10] Green, J. O. \& Burleson. B. R (Eds). (2003). Handbook of Communication and Social Interaction Skills. London: Lawrence Erlbaum Associates, Publishers.

[11] Henning, J. E. (2008). The Art of Discussion-Based Teaching: Opening Up Conversation in the Classroom. New York: Routledge.

[12] Hughes, R. (2011). Teaching and Researching Speaking. New Delhi: Pearson.

[13] Kozar, O. (2018). Teaching Conversational English to Adult Learners via Skype: A Russian Perspective. Anne Burns and Joseph Siegel (Eds.), International Perspectives on Teaching the Four Skills in ELT (pp. 125-140). Cham, Switzerland: Palgrave Macmillan.

[14] Lave, J. (1998). Communities of Practice. Cambridge: Cambridge University Press.

[15] Molder, H. T. \& Potter, J. (2005). Conversation and Cognition. Cambridge: Cambridge University Press.

[16] Nolasco, R. \& Lois, A. (1987). Conversation. Oxford: Oxford University Press.

[17] Sasikumar, V. \& Dhamija, P. V. (1993). Spoken English: A Self-Learning Guide to Conversation Practice. New Delhi: Tata McGraw-Hill Publishing Company Limited.

[18] Sasson, D. (2013). Speaking and Writing for English Language Learners: Collaborative Teaching for Greater Success with K-6. Lanham: Rowman \& Littlefield Publishers, Inc.

[19] Swales, J. M. (1990). Genre analysis: English in Academic and Research Settings. Cambridge: Cambridge University Press.

[20] Turnbull, W. (2003). Language in Action: Psychological Models of Conversation. New York: Psychology Press.

[21] Worth, R. (2004). Communication Skills. $2^{\text {nd }}$ ed. New York: Ferguson.

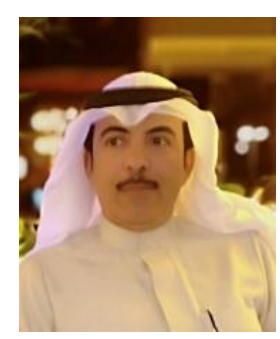

Mohammad Almutairi is an assistant professor and the Head of English Language Unit, The Language Center, College of Basic Education, State of Kuwait. He has been involved in teaching EFL for college students since 1992 among different colleges: College of Business Studies, College of Technological Studies and finally College of Basic Education. He has earned his BA in English Language\& Linguistics from Kuwait University in 1992, M.A. in Education (ELT) from the University of East Anglia, U.K. in 2003, and PhD in English Language and TESOL from the University of Leeds met in 2012. His main interests are Language \& Culture, TESOL \& TEFL. 